\title{
Modulation of sex hormone secretion in cows by acute infection with bovine viral diarrhoea virus
}

\author{
M. D. Fray ${ }^{1 *}$, G. E. Mann², E. C. L. Bleach³, P. G. Knight ${ }^{1}$, \\ M. C. Clarke ${ }^{1}$ and B. Charleston ${ }^{1}$ \\ ${ }^{1}$ Institute for Animal Health, Compton, Newbury RG20 7NN, UK; ${ }^{2}$ University of Nottingham, \\ Sutton Bonington LE12 5RD, UK; and ${ }^{3}$ University of Reading, Whiteknights, \\ Reading RG6 6AJ, UK
}

Bovine viral diarrhoea virus (BVDV) is a major pathogen of cattle and is responsible for considerable reproductive loss. In this study, the in vivo responses in six multiparous cows were investigated after a non-cytopathogenic BVDV challenge (strain Pe 515; $5 \times 10^{6}$ tissue culture infective dose 50) given 9 days before a synchronized ovulation. Six similar cows challenged with non-infectious culture medium served as controls. The experimental noncytopathogenic BVDV infection was followed by a viraemia and leucopenia at days 5-9 after challenge, but no other clinical signs of infection were detected. However, the BVDV infection altered endocrine function. Mean LH pulse frequency immediately before CIDR withdrawal was lower $(P \leq 0.05)$ in the BVDV-infected $(2.17 \pm 0.34$ pulses per $8 \mathrm{~h})$ compared with the sham-infected $(4.83 \pm 1.04$ pulses per $8 \mathrm{~h}$ ) animals. At day 3 after CIDR withdrawal, plasma oestradiol concentrations remained high $(P<0.05)$ in the infected cows $\left(2.19 \pm 0.51 \mathrm{pg} \mathrm{ml}^{-1}\right)$ compared with the sham-infected controls $\left(0.72 \pm 0.29 \mathrm{pg} \mathrm{ml}^{-1}\right)$. However, there was no difference in the peak oestradiol concentration (BVDV: $2.31 \pm 0.29$ versus sham: $2.34 \pm 0.41 \mathrm{pg}$ $\mathrm{ml}^{-1}$ ). In addition, non-cytopathogenic BVDV significantly $(P<0.05)$ increased the duration of the interval between ovulation and onset of the postovulatory progesterone increase (values $>1.0 \mathrm{ng} \mathrm{ml}^{-1}$ ) (BVDV: $3.0 \pm 0.26$ versus sham: $4.0 \pm 0.26$ days). The viral infection also significantly $(P<0.01)$ decreased mean plasma progesterone concentrations between day 3 and day 11 after ovulation (BVDV: $2.59 \pm 0.32$ versus sham: $4.13 \pm 0.27 \mathrm{ng} \mathrm{ml}^{-1}$ ). These data show that non-cytopathogenic BVDV viraemias during the follicular phase can modulate the secretion of gonadotrophins and sex steroids, in particular progesterone, during a synchronized oestrous cycle. Therefore, viraemias during the follicular phase may reduce the fertility of cattle by disrupting the capacity of the ovulatory follicle to form a competent corpus luteum, thereby compromising early embryo development and maternal recognition of pregnancy.

\section{Introduction}

Bovine viral diarrhoea virus (BVDV), classical swine fever virus and border disease virus comprise the pestivirus genus within the Flaviviridae. BVDV is a major cattle pathogen with a global distribution and, in common with the other pestiviruses, it is an enveloped virus with a positive-sense, single stranded RNA genome (for a review, see Nettleton and Entrican, 1995). BVDV exists as two distinct biotypes, which can be distinguished by their cytopathogenicity on cultured cells. In addition, fetuses inoculated with noncytopathogenic BVDV can develop an immunotolerant and persistent infection, which cannot be established with the cytopathogenic biotype (Brownlie et al., 1989). Cattle carrying a persistent infection maintain a reservoir of BVDV within cattle populations and represent the principal route

*Present address: FESA Unit, MRC Harwell, Harwell, Didcot OX11 ORD, UK

Email:m.fray@har.mrc.ac.uk of viral transmission between herd-mates. However, the infections with BVDV can also be transmitted through infected semen, vaccines, fomites and fluids used for embryo transfer.

In cows, pre- and postnatal infections are associated with a variety of disease syndromes that include immune suppression, congenital defects, abortion, mucosal disease and, importantly, disruption of reproductive function. Field outbreaks of non-cytopathogenic BVDV are commonly associated with conception failure and an increased incidence of early abortion (Roeder and Drew, 1984; Larsson et al., 1994; Virakul et al., 1998). Viraemias induced experimentally during the follicular phase have resulted in a $50 \%$ decrease in pregnancy rate and a deterioration in the quantity and quality of embryos recovered after superovulation (McGowan et al., 1993; Kafi et al., 1997). Viraemia during the luteal phase can retard follicle development (Grooms et al., 1998a).

Despite the established link between non-cytopathogenic BVDV infection and poor fertility, the underlying mechanisms have not been elucidated. Pestiviruses, and BVDV in 
particular, have a broad tissue tropism infecting many cell types including thecal, granulosa and luteal cells, oocytes (Booth et al., 1995; Grooms et al., 1996; Fray et al., 1998), pituitary gonadotrophs (Anderson et al., 1987) and central nervous tissue (Hewicker-Trautwein et al., 1995). Clearly, non-cytopathogenic BVDV has the potential to disrupt cell function within one or more components of the hypothalamic-pituitary-ovarian axis.

Nevertheless, there is no compelling evidence to indicate that blastomeres from in vivo-derived, zona pellucida-intact embryos can be infected with non-cytopathogenic BVDV, although blastomeres themselves are permissive to infection (Vanroose et al., 1998). Studies in vitro have failed to show conclusively that non-cytopathogenic BVDV compromises embryo development directly (Guerin et al., 1992; Zurovac et al., 1994; Stringfellow et al., 1997, 2000). As a consequence, investigations into the causes of poor fertility in non-cytopathogenic BVDV-infected cattle are now focusing on the interaction between the virus and ovarian-endometrial function.

Fray et al. (1999) showed that viraemia has deleterious effects on follicular function. Viraemia induced during the first 2-6 days of the oestrous cycle suppressed oestradiol secretion from the first dominant postovulatory follicle, although the mechanism was unresolved. The present study was designed to establish whether a non-cytopathogenic BVDV viraemia during the follicular phase could disrupt gonadotrophin or ovarian steroid secretion in cows.

\section{Materials and Methods}

\section{Animals}

This experiment was performed in 12 non-lactating, multiparous Friesian/Holstein cows following procedures approved by the local ethics committee. The animals were all derived from the same farm and were confirmed BVDV naive before the experiment started. The study was conducted in the disease isolation facility at the Institute for Animal Health to minimize the possibility of adventitious infection. On entry to the isolation facility, the cows were allocated at random to each treatment group and housed in individual loose boxes. During the study period the cows were fed hay and water ad libitum, plus a $4 \mathrm{~kg}$ concentrate supplement (16\% (w/w) protein), fed twice a day.

Oestrous cycles were synchronized with 11 days of progesterone therapy (CIDR: InterAg, Hamilton) plus a prostaglandin injection $\left(2.0 \mathrm{ml}\right.$ Estrumate $^{\circledR}$; Schering-Plough, Welwyn Garden City) at the time of CIDR withdrawal. Five days before CIDR withdrawal, six cows were challenged intranasally with $5.0 \mathrm{ml}$ non-cytopathogenic BVDV (Pe $515 ; 5 \times 10^{6} \mathrm{TCID}_{50}$ ) so that the predicted period of viraemia coincided with the final stages of preovulatory follicle development. The remaining six cows were challenged with $5.0 \mathrm{ml}$ of cell-conditioned, non-infectious culture medium. On the day before the experimental challenge each cow was fitted with an indwelling jugular vein catheter to facilitate collection of blood samples. The catheters remained in place throughout the study.

Daily blood samples $(10.0 \mathrm{ml})$ were collected from 2 days before, until 34 days after, the viral challenges for haematological analysis, virus isolation, and progesterone and oestradiol analysis. Rectal temperatures were also determined from 2 days before, until 14 days after, the BVDV challenge. Blood samples $(5.0 \mathrm{ml})$ were collected at $20 \mathrm{~min}$ intervals over four separate $8 \mathrm{~h}$ periods (the $8 \mathrm{~h}$ period immediately before CIDR withdrawal and then for $8 \mathrm{~h}$ periods starting 16, 40 and $64 \mathrm{~h}$ later) to follow $\mathrm{LH}$ secretion during the synchronized follicular phase. In addition, samples were collected at $8 \mathrm{~h}$ intervals during the follicular phase and early luteal phase to detect the preovulatory LH surge.

\section{Histology}

The cows were killed between day 35 and day 37 after each experimental challenge and the reproductive tracts were recovered for histological examination. Follicular fluid was aspirated from the largest follicle on each ovary and frozen at $-20^{\circ} \mathrm{C}$ until analysed for BVDV antibody titre. Sections from both ovaries were fixed in $10 \%(\mathrm{v} / \mathrm{v})$ formal saline before embedding in paraffin wax and histological staining with haematoxylin and eosin. Additional samples were cryopreserved in OCT compound before indirect immunofluorescent staining for BVDV antigens following the method of Fray et al. (1998), with the exception that mouse monoclonal antibody $15 \mathrm{C}_{5}$ was used as the primary antibody. This reagent was raised against the structural glycoprotein $\mathrm{E}^{\mathrm{rns}}$ (Haines et al., 1992).

\section{$B V D V$ isolation and titration of $B V D V$ neutralizing antibody}

Virus isolations were conducted on calf testis epithelial cells (CTECs) cultured on coverslips in stoppered tubes. Each blood sample $(0.2 \mathrm{ml}$ whole blood) was tested in triplicate and cultured for 5 days at $36^{\circ} \mathrm{C}$. The presence of BVDV was detected by indirect immunofluorescent staining using polyclonal anti-BVDV serum. Negative cultures were passaged once through culture to confirm the absence of BVDV. Titration of the virus was not performed.

Virus neutralizing antibody titres were determined using a test based on the microtitre assay of Frey and Liess (1971), in which $0.1 \mathrm{ml}$ samples of serum were diluted in culture media, in a twofold dilution series, with $100 \mathrm{TCID}_{50} \mathrm{ml}^{-1}$ of the cytopathogenic BVDV isolate NADL. After a $1 \mathrm{~h}$ incubation, the medium was added to CTEC cultures grown on coverslips in stoppered tubes. Each serum sample was tested in triplicate and cultured for 5 days at $36^{\circ} \mathrm{C}$. The occurrence of cell death induced by cytopathogenic BVDV was detected visually. The virus neutralizing antibody titre was calculated from the reciprocal of the serum dilution that neutralized the cytopathogenic BVDV. Negative cultures were passaged once through culture to confirm the absence of BVDV neutralization. 


\section{Hormone assays}

Plasma progesterone concentrations were measured by the radioimmunoassay described by Haresign et al. (1975). The assay had a limit of sensitivity of $0.5 \mathrm{ng} \mathrm{ml}-1$, with intraand interassay coefficients of variation of $<10 \%$ and $8.7 \%$, respectively.

Plasma oestradiol concentrations were measured using a radioimmunoassay based on reagents supplied in an assay kit produced by Serono Diagnostics as modified by Mann et al. (1995). The assay had a limit of sensitivity of $0.3 \mathrm{pg} \mathrm{ml}^{-1}$, with inter- and intra-assay coefficients of variation of $<10.0 \%$ and $12.9 \%$, respectively.

Plasma LH concentrations were measured by radioimmunoassay as described by Beard et al. (1990) using EHC-bLH-1 (Leoder et al., 1987) as the standard. The assay had a limit of sensitivity of $0.8 \mathrm{ng} \mathrm{ml}^{-1}$, with inter- and intra-assay coefficients of variation of $<11.5 \%$ and $8.2 \%$, respectively.

\section{Ovarian follicle and luteal development}

Ovulatory follicle growth was monitored daily from the day of CIDR removal until ovulation (defined as the day on which a follicle $>10 \mathrm{~mm}$ in diameter identified on previous days disappeared) by transrectal ultrasonography as described by Pierson and Ginther (1988). A real-time B mode ultrasound scanner (Concept 2000; Dynamic Imaging, Livingstone) fitted with a $7.5 \mathrm{mHz}$ linear array transducer was used. The size of the subsequent corpus luteum was determined at day 15 after CIDR removal.

\section{Statistical analysis}

Individual $\mathrm{LH}$ pulses were identified using the Munro pulse analysis package (Zaristow Software, West Mosham) and were defined as an increase in plasma $\mathrm{LH}>6 \mathrm{SD}$ from the baseline occurring not less than 30 min after the previous nadir and with two or more points comprising each pulse. LH pulse frequency, interval to the first increase in progesterone $>1.0 \mathrm{ng} \mathrm{ml}^{-1}$ and the duration of progesterone secretion (progesterone concentrations consistently $>1.0 \mathrm{ng} \mathrm{ml}^{-1}$ ) were analysed by Mann-Whitney nonparametric test. Changes in oestradiol and progesterone secretion were analysed by repeated measures ANOVA. All other data were analysed by Student's $t$ test or two-way ANOVA. All data are mean \pm SEM.

\section{Results}

At the start of the study, the postpartum interval (BVDV: $392.3 \pm 77.4$ versus sham: $323.2 \pm 72.7$ days) and body weights (BVDV: $704.2 \pm 40.2$ versus sham: $682.5 \pm 40.1 \mathrm{~kg}$ ) were similar between each group.

\section{Virology and leucopenia}

A viraemia was detected on at least two occasions in all six cows challenged with BVDV (Table 1). In each case, the
Table 1. Bovine viral diarrhoea virus (BVDV) isolations from whole blood after an intranasal challenge with non-cytopathogenic virus $\left(\right.$ Pe 515: $\left.5 \times 10^{6} \mathrm{TCID}_{50}\right)$

\begin{tabular}{lcccccc}
\hline \multirow{7}{*}{$\begin{array}{l}\text { Day from } \\
\text { challenge }\end{array}$} & 86 & 93 & 104 & 209 & 213 & 294 \\
\cline { 2 - 6 } & & & & & & \\
\hline 0 & $---^{\mathrm{a}}$ & --- & --- & --- & --- & --- \\
3 & --- & --- & --- & --- & --- & --- \\
5 & --- & $-++\mathrm{b}$ & -+- & --- & -++ & -++ \\
6 & ++- & +++ & --- & -++ & +++ & --+ \\
7 & +++ & +++ & +++ & -++ & -++ & -++ \\
10 & --- & +-- & -++ & --- & --- & --- \\
14 & --- & --- & --- & --- & --- & --- \\
21 & --- & --- & --- & --- & --- & --- \\
28 & --- & --- & --- & --- & --- & --- \\
34 & --- & --- & --- & --- & --- & --- \\
\hline
\end{tabular}

aVirus isolations set up in triplicate cultures to confirm the presence or absence of BVDV. Each + or - sign denotes the outcome of an individual culture.

bThe virus isolations set up in triplicate cultures confirm the presence of BVDV in two of three cultures.

$\mathrm{TCID}_{50}$ : tissue culture infective dose 50.

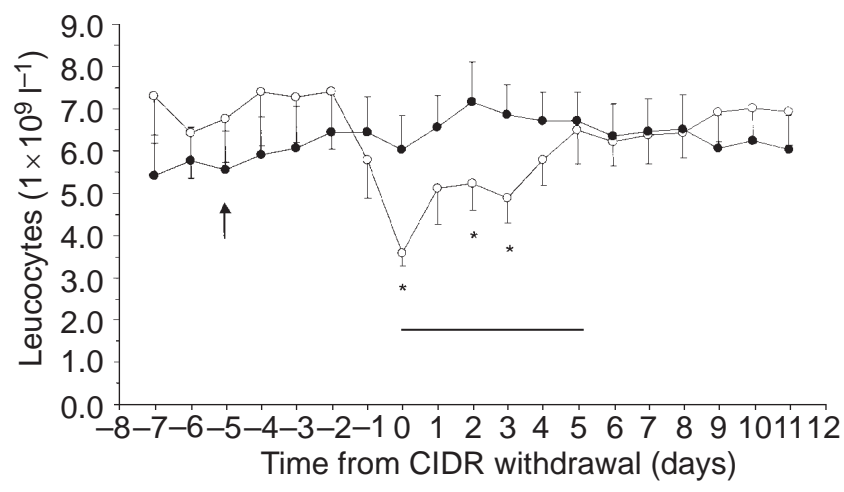

Fig. 1. Leucocyte counts of cows after an intranasal challenge with non-cytopathogenic bovine viral diarrhoea virus (BVDV) $(n=6$; $\bigcirc)$ or non-infectious culture medium $(n=6$; $)$. The data have been synchronized from the onset of luteolysis. The arrow indicates the time of challenge and the horizontal bar represents the period of viraemia. Data are mean \pm SEM. *Individual time point is significantly different from the corresponding control value $(P<0.05)$.

viraemia was detected within 1 day of CIDR withdrawal (during the preovulatory period) and was accompanied by a transient leucopenia (Fig. 1). However, the experimental challenges were not accompanied by any clinical signs of infection. Likewise, rectal temperatures were similar in the BVDV- $\left(37.8-38.8^{\circ} \mathrm{C}\right)$ and sham- $\left(37.8-39.2^{\circ} \mathrm{C}\right)$ infected cattle. Neither viraemia nor leucopenia was detected in any of the sham-infected cows. 


\section{Hormone data}

During the $8 \mathrm{~h}$ period immediately before CIDR withdrawal, LH pulse frequency was lower $(P \leqslant 0.05)$ in the BVDV-infected cows $(2.17 \pm 0.34$ pulses per $8 \mathrm{~h})$ compared with the sham-infected cows $(4.83 \pm 1.04$ pulses per $8 \mathrm{~h}$ ). However, during this period there was no significant difference in the mean $\mathrm{LH}$ pulse amplitude (BVDV: $1.31 \pm 0.10$ versus sham: $1.59 \pm 0.27 \mathrm{ng} \mathrm{ml}^{-1}$ ) or mean plasma $\mathrm{LH}$ concentration (BVDV: $1.38 \pm 0.23$ versus sham: $1.45 \pm 0.12 \mathrm{ng} \mathrm{ml}^{-1}$ ). Similarly, neither $\mathrm{LH}$ pulse frequency (BVDV: $7.83 \pm 1.04$ versus sham: $6.67 \pm 0.67$ pulses per $8 \mathrm{~h}$ ) nor LH pulse amplitude (BVDV: $1.25 \pm 0.11$ versus sham: $1.59 \pm 0.30 \mathrm{ng} \mathrm{ml}^{-1}$ ) differed between the treatment groups during the initial 16-24 $\mathrm{h}$ after CIDR withdrawal.

The mean plasma $\mathrm{LH}$ concentrations recorded during the four periods of 20 min blood sampling are shown (Fig. 2). The histograms represent tonic LH secretion, with values corresponding to ongoing preovulatory LH surges (consecutive samples $>5.0 \mathrm{ng} \mathrm{ml}^{-1}$ ) omitted. In both groups, CIDR withdrawal was followed by an increase in plasma LH concentrations compared with the concentrations recorded during the final $8 \mathrm{~h}$ of CIDR emplacement. For the BVDV-infected cows, this increase reached significance $(P<0.01)$ during the time periods $16-24 \mathrm{~h}$ $\left(1.17 \pm 0.19 \mathrm{ng} \mathrm{ml}^{-1}\right)$ and $40-48 \mathrm{~h}\left(1.33 \pm 0.25 \mathrm{ng} \mathrm{ml}^{-1}\right)$ after CIDR withdrawal. In contrast, a significant $(P<0.01)$ increase $\left(0.82 \pm 0.14 \mathrm{ng} \mathrm{ml}^{-1}\right)$ in plasma $\mathrm{LH}$ concentrations was recorded only in the sham-infected cows between $16 \mathrm{~h}$ and $24 \mathrm{~h}$ after CIDR withdrawal. Consequently, between $40 \mathrm{~h}$ and $48 \mathrm{~h}$ after CIDR withdrawal, plasma $\mathrm{LH}$ concentrations were significantly $(P<0.01)$ higher in the BVDV-infected cows $\left(2.71 \pm 0.24 \mathrm{ng} \mathrm{ml}^{-1}\right)$ compared with the sham-infected controls $\left(1.76 \pm 0.17 \mathrm{ng} \mathrm{ml}^{-1}\right)$.

The duration of the interval between CIDR withdrawal and the preovulatory $\mathrm{LH}$ surge was longer in the BVDVinfected cows $(61.33 \pm 6.66 \mathrm{~h})$ compared with the shaminfected animals $(42.67 \pm 10.03 \mathrm{~h})$, but this difference was not significant. The large standard error recorded in the sham-infected cows was linked to one cow that underwent an LH surge at $88 \mathrm{~h}$ after CIDR withdrawal (more than twice the group average). Reanalysis of the LH surge data on the basis of the cows that possessed ovarian follicles with diameters $>7.3 \mathrm{~mm}$ at the time of CIDR withdrawal revealed a significantly longer $(P<0.05)$ interval between luteolysis and the LH surge in the BVDV-infected cows $(60.80 \pm 7.41 \mathrm{~h} ; n=5)$ compared with the sham-infected animals (33.60 $\pm 1.60 \mathrm{~h} ; n=5)$.

Plasma oestradiol profiles for the BVDV- and shaminfected cows recorded throughout the synchronized oestrous cycle are shown (Fig. 3). A comparison of mean plasma oestradiol concentrations recorded during the 3 day period before infection with the 5 day period between infection and CIDR withdrawal revealed a significant $(P<0.01)$ increase in the sham-infected animals $(0.51 \pm 0.04$ versus $0.91 \pm 0.12 \mathrm{pg} \mathrm{ml}^{-1}$, respectively). A similar increase in oestradiol secretion was not evident in the BVDV-

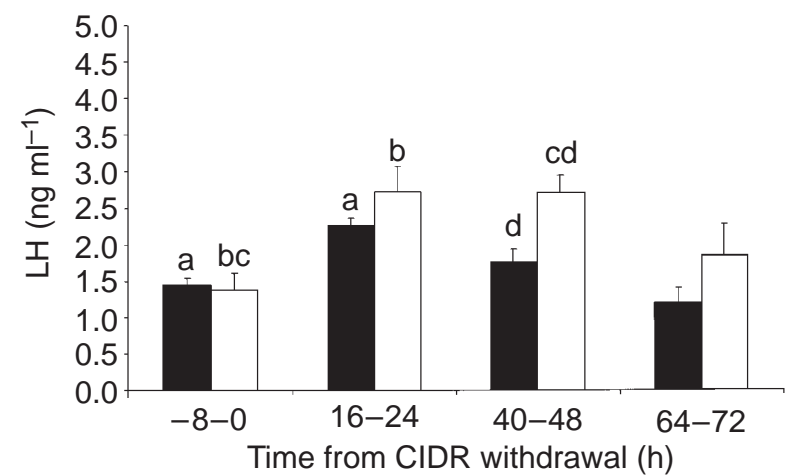

Fig. 2. Plasma LH concentrations of cows during the $8 \mathrm{~h}$ immediately before the onset of luteolysis, and during the $8 \mathrm{~h}$ starting at 16, 40 and $64 \mathrm{~h}$ after the onset of luteolysis. Cows were challenged with non-cytopathogenic bovine viral diarrhoea virus (BVDV) $(n=6 ; \square)$ and non-infectious culture medium $(n=6 ; \square)$. The experimental challenges were given 5 days before luteolysis. Data are mean \pm SEM. ${ }^{a-d}$ Individual time points with common superscripts are significantly different $(P<0.01)$.

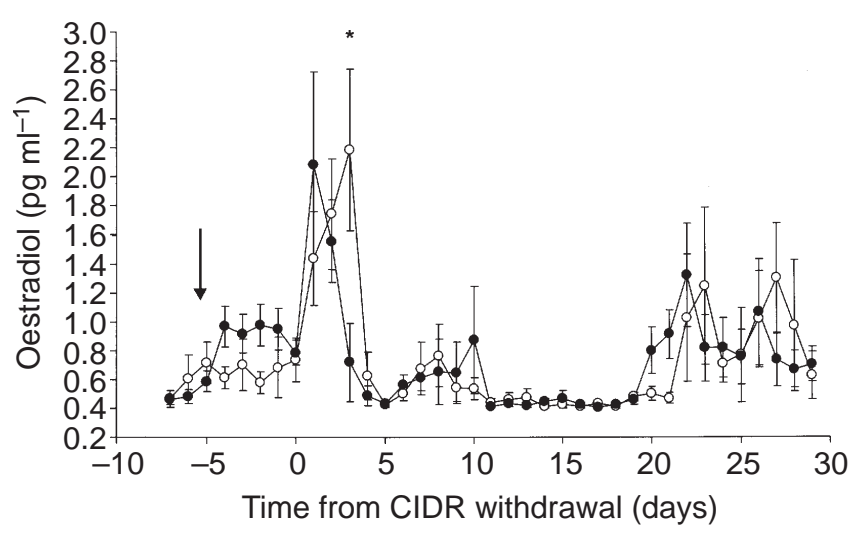

Fig. 3. Daily plasma oestradiol concentrations in cows after an intranasal challenge with non-cytopathogenic bovine viral diarrhoea virus (BVDV) $(n=6 ; \bigcirc)$ or non-infectious culture medium $(n=6$; $)$. The data have been synchronized from the onset of luteolysis. The arrow indicates the time of challenge. Data are mean \pm SEM. *Individual time point is significantly different from the corresponding control value $(P<0.05)$.

infected animals $\left(0.60 \pm 0.09\right.$ versus $\left.0.67 \pm 0.12 \mathrm{pg} \mathrm{ml}^{-1}\right)$. However, on the day of CIDR withdrawal, plasma oestradiol concentrations had decreased in the sham-infected cows and the values were similar between the two groups (BVDV: $0.74 \pm 0.14$ versus sham: $0.79 \pm 0.09 \mathrm{pg} \mathrm{ml}^{-1}$ ).

After CIDR withdrawal, plasma oestradiol concentrations increased to a similar extent in both groups, but at day 3 after CIDR withdrawal plasma oestradiol concentrations remained significantly $(P<0.05)$ higher in the BVDV-infected cows (BVDV: $2.19 \pm 0.51$ versus sham: $0.72 \pm 0.29 \mathrm{pg} \mathrm{ml}^{-1}$ ). However, there was no difference in the peak oestradiol concentration (BVDV: $2.31 \pm 0.29$ 


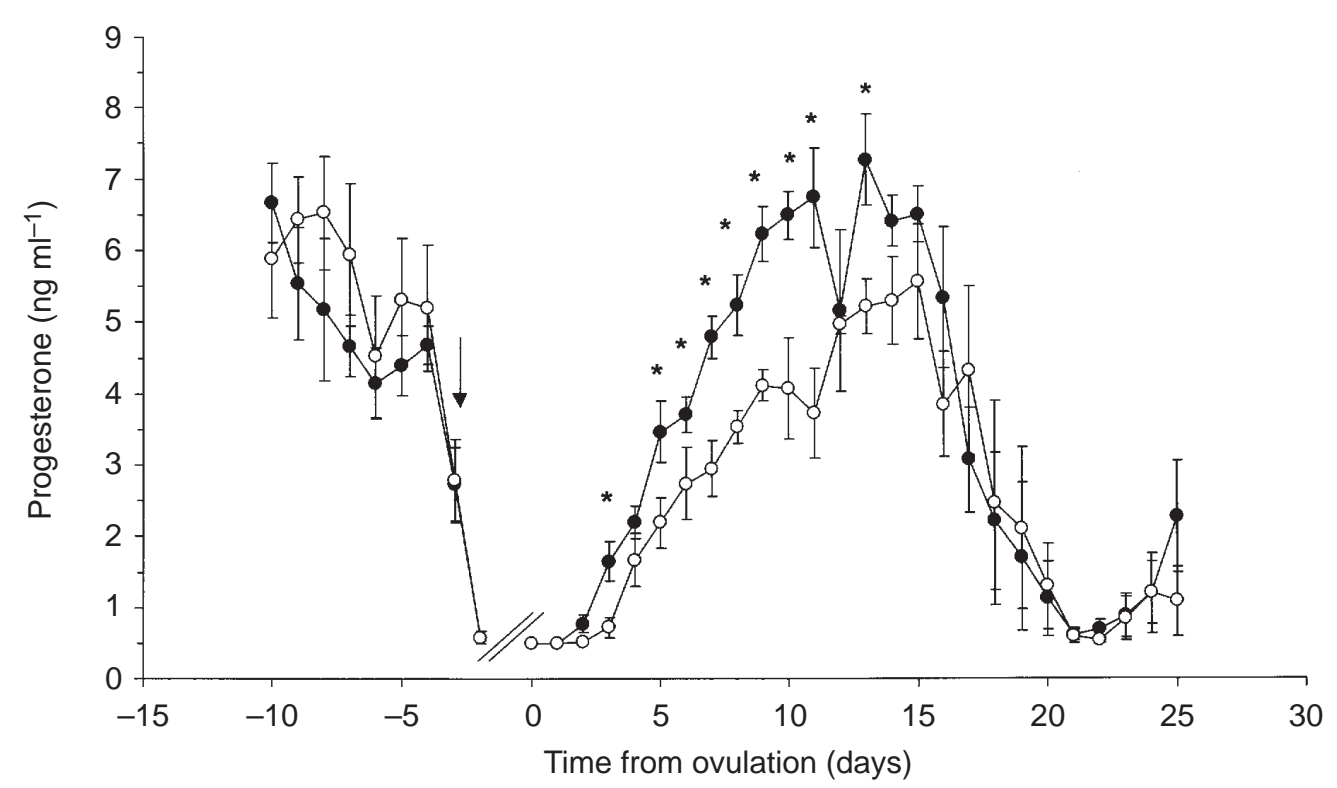

Fig. 4. Daily plasma progesterone concentrations in cows after an intranasal challenge with noncytopathogenic bovine viral diarrhoea virus (BVDV) $(n=6 ; 0)$ or non-infectious culture medium $(n=6$; $)$. The data have been synchronized about the day of ovulation, confirmed by transrectal ultrasonography. The arrow indicates the time of CIDR withdrawal. *Individual time point is significantly different from the corresponding control value $(P<0.05)$.

versus sham: $2.34 \pm 0.41 \mathrm{pg} \mathrm{ml}^{-1}$ ) attained during the synchronized follicular phase or in the duration of the interval between successive preovulatory peaks (BVDV: $22.83 \pm 0.48$ versus sham: $22.50 \pm 0.72$ days).

The mean plasma progesterone profiles synchronized to the time of ovulation are shown (Fig. 4). After ovulation, which was confirmed by plasma oestradiol analysis and ovarian ultrasonography, plasma progesterone concentrations increased more slowly in the BVDV-infected cows. The duration of the interval between ovulation and the first day on which plasma progesterone concentrations increased to $>1.0 \mathrm{ng} \mathrm{ml}^{-1}$ was significantly longer $(P<0.05)$ in the BVDV-infected cows (BVDV: $4.0 \pm 0.26$ versus sham: $3.0 \pm 0.26$ days).

In addition, the mean concentration of plasma progesterone recorded between day 3 and day 11 after ovulation (during the postovulatory increase) was suppressed $(P<0.01)$ by the BVDV infection (BVDV: $2.59 \pm 0.32$ versus sham: $4.13 \pm 0.27 \mathrm{ng} \mathrm{ml}^{-1}$ ). Peak luteal phase progesterone concentrations were also suppressed $(P<0.05)$ by infection (BVDV: $6.56 \pm 0.53$ versus sham: $8.32 \pm 0.43 \mathrm{ng} \mathrm{ml}^{-1}$ ), but the duration of the luteal phase did not differ between the BVDV-infected (18.83 \pm 0.77 days) and sham-infected $(18.33 \pm 0.78$ days $)$ cows.

\section{Follicular growth rates}

Preovulatory follicle development and the diameters of the subsequent corpora lutea are shown (Table 2). On the day of CIDR withdrawal, the mean diameter of the presumptive ovulatory follicle was similar in the BVDV$(10.6 \pm 1.5 \mathrm{~mm})$ and sham- (13.4 $\pm 1.4 \mathrm{~mm})$ infected cows. Likewise, the maximum diameters attained by the preovulatory follicles were not affected by the viral infection (BVDV: $14.3 \pm 0.7$ versus sham: $16.0 \pm 0.8 \mathrm{~mm}$ ). Consistent with follicle data, the diameters of the corpora lutea at day 15 after CIDR withdrawal were similar between the BVDV$(20.2 \pm 1.5 \mathrm{~mm})$ and sham- $(20.2 \pm 1.1 \mathrm{~mm})$ infected cows

\section{Serum and follicular fluid antibodies}

All the infected cows sero-converted to BVDV and developed appreciable neutralizing antibody titres at the end of the study (Table 3). In addition, BVDV antibodies were detected in follicular fluid samples taken from each cow at the time of death. Although there was a significant correlation $(r=68.4, P<0.05)$ between serum and follicular fluid antibody titres, the titres were $42.01 \pm 4.51 \%$ lower in the follicular fluid samples. None of the sham-infected cows sero-converted to BVDV during the study.

\section{Immunohistochemistry}

Immunofluorescent staining of BVDV antigen $E^{\text {rns }}$ was not detected in any of the ovarian tissues collected from either the BVDV-infected or the sham-infected cows (data not shown). In addition, histological examination of formalinfixed sections did not detect any histological lesions in the tissues. 
Table 2. Ovarian follicular dynamics recorded by transrectal ultrasonography after an intranasal challenge with non-cytopathogenic bovine viral diarrhoea virus (BVDV; Pe 515: $5 \times 10^{6} \mathrm{TCID}_{50}$ ) or non-infectious culture medium

\begin{tabular}{lcc}
\hline & $\begin{array}{c}\text { BVDV-infected } \\
\text { cattle }(n=6)\end{array}$ & $\begin{array}{c}\text { Sham-infected } \\
\text { cattle }(n=6)\end{array}$ \\
\hline $\begin{array}{c}\text { Diameter of the ovulatory } \\
\text { follicle on days of CIDR } \\
\text { withdrawal (mm) }\end{array}$ & $10.6 \pm 1.5$ & $13.3 \pm 1.4$ \\
$\begin{array}{l}\text { Maximum diameter of } \\
\text { ovulatory follicle (mm) }\end{array}$ & $14.3 \pm 0.7$ & $16.0 \pm 0.8$ \\
$\begin{array}{l}\text { Growth rate of ovulatory } \\
\text { follicle (mm day-1) }\end{array}$ & $0.9 \pm 0.2$ & $0.7 \pm 0.1$ \\
$\begin{array}{c}\text { Corpus luteum diameter } \\
\text { recorded at day 15 after } \\
\text { CIDR withdrawal (mm) }\end{array}$ & $20.2 \pm 1.1$ & $20.2 \pm 1.5$ \\
\hline
\end{tabular}

There were no significant differences between the two groups. $\mathrm{TCID}_{50}$ : tissue culture infective dose 50 .

Table 3. Bovine viral diarrhoea virus (BVDV) neutralizing antibody titres in serum and follicular fluids after an intranasal challenge with non-cytopathogenic virus (Pe 515: $5 \times 10^{6} \mathrm{TCID}_{50}$ )

\begin{tabular}{lcccccc}
\hline & \multicolumn{6}{c}{ Cow identification } \\
\cline { 2 - 7 } $\begin{array}{l}\text { Day from } \\
\text { challenge }\end{array}$ & 86 & 93 & 104 & 209 & 213 & 294 \\
\hline 0 & - & - & - & - & - & - \\
7 & - & - & - & - & - & - \\
14 & - & - & - & $2^{\mathrm{a}}$ & - & - \\
21 & 6 & 6 & 6 & 24 & 12 & 32 \\
28 & 32 & 24 & 32 & 64 & 24 & 48 \\
34 & 64 & 64 & 48 & 128 & 96 & 64 \\
35 & & & & & & \\
37 & 24 & - & 24 & - & 36 & - \\
\hline
\end{tabular}

Days 0, 7, 14, 21, 28 and 34: serum neutralizing antibody titres are shown. Days 35 and 37: mean neutralizing antibody titres in follicular fluid are shown. aNeutralizing antibody titre is calculated from the reciprocal of the maximum dilution factor able to neutralize the cytopathogenic effect induced by $100 \mathrm{TCID}_{50}$ of the cytopathic BVDV strain NADL.

$\mathrm{TCID}_{50}$ : tissue culture infective dose 50

\section{Discussion}

The detection of a transient viraemia, leucopenia and the subsequent generation of BVDV neutralizing antibodies in each cow challenged with virus are typical of experimental non-cytopathogenic BVDV infections. These data indicate that a productive infection was established although no clinical signs of disease were observed. The absence of clinical signs concurs with our previous experience with this virus (Fray et al., 1999), supporting the contention that the treatment effects reported in the present study resulted from a specific viral effect on cellular interactions along the hypothalamic-pituitary-ovarian axis and were not a consequence of an overt febrile response to infection.

Immediately before CIDR withdrawal (on day 5 after challenge), BVDV infection was associated with a 50\% reduction in LH pulse frequency compared with the shaminfected controls. However, this effect was not maintained beyond $16 \mathrm{~h}$ after CIDR withdrawal, at which time a typical follicular phase increase in $\mathrm{LH}$ secretion was recorded in both treatment groups. These data imply that noncytopathogenic BVDV can reduce LH secretion when progesterone, but not oestradiol, concentrations, are increased. The maintenance of high plasma $\mathrm{LH}$ concentrations in the BVDV-infected cows during the 40-48 h intensive blood sampling period reflects the difference in the timing of the preovulatory $\mathrm{LH}$ surges. In fact, the duration of the mean interval between CIDR withdrawal and the preovulatory LH surge was extended by the viral infection. However, this difference was only significant in five out of six cows from each group that possessed large ovarian follicles (>7.3 $\mathrm{mm}$ in diameter) at the time of CIDR withdrawal. Clearly, the delayed LH surges were not a consequence of inadequate follicular phase LH or oestradiol secretion, indicating that non-cytopathogenic BVDV may also be able to alter the pituitary-hypothalamic sensitivity to oestradiol positive feedback.

Fray et al. (1999) showed that non-cytopathogenic BVDV can reduce oestradiol secretion from non-ovulatory follicles when progesterone concentrations are high. This observation is in agreement with the results of the present study showing that the non-cytopathogenic BVDV suppressed oestradiol concentrations between day 1 and day 5 after infection. The reduction in LH pulse frequency that accompanied the BVDV infection may help to explain how the virus can reduce tonic oestradiol secretion, particularly in view of the fact that mean plasma progesterone concentrations were similar between the infected and control animals during CIDR emplacement. These data lend further support to the contention that non-cytopathogenic BVDV can enhance steroid negative feedback to the hypothalamus when plasma progesterone concentrations are high.

In contrast to the suppression of oestradiol secretion during the luteal phase, the magnitude of the oestradiol increase immediately after CIDR withdrawal was not affected by BVDV infection. However, the viral infection did delay the peak and extend the duration of preovulatory oestradiol secretion, an observation which is consistent with those of Kafi et al. (1997), who reported a 12 h delay in the expression of oestrus in cows superovulated with FSH-P (a porcine pituitary extract) during a non-cytopathogenic BVDV viraemia. These data provide some additional evidence for a virally induced lesion in the steroid feedback mechanisms and for insensitivity to oestradiol positive feedback in the presence of 'normal' follicular phase LH secretion.

Consistent with the disruption of normal oestradiol secretion, aberrant plasma progesterone profiles were also 
recorded in the BVDV-infected cows. The BVDV infection extended the duration of the interval between ovulation and the day on which a plasma progesterone concentration $>1.0 \mathrm{ng} \mathrm{ml}^{-1}$ was first recorded. In addition, the virus suppressed plasma progesterone concentrations between day 3 and day 11 after ovulation but had no measurable effect on corpus luteum diameter at day 15 after CIDR withdrawal. However, by day 15 after ovulation, plasma progesterone concentrations are not related to corpus luteum diameter (G. E. Mann, unpublished).

The virus-induced suppression of progesterone secretion contrasts with previous data generated in this laboratory and elsewhere (Grooms et al., 1998a; Fray et al., 1999), and probably reflects differences in the timing of the BVDV challenge and experimental design. The timing of the induced viraemia could have a critical bearing on the outcome of infection. Van Der Maaten and Miller (1985) and Miller and Van Der Maaten (1986) demonstrated that the severity of lesions in the corpus luteum was greater in heifers infected with bovine herpes virus 1 (BHV-1) at oestrus compared with later stages of the cycle. These authors concluded that the severity of the lesion profile was related to neovascularization of the theca interna and that when there is maximum blood pooling during remodelling of corpora lutea a large number of cells are exposed simultaneously to virus. A similar situation is likely to occur with non-cytopathogenic BVDV even in the absence of overt pathology.

Even in the absence of necrotic ovarian lesions, the suppression in progesterone secretion during the luteal phase indicates a potential mechanism through which non-cytopathogenic BVDV may compromise conception in cows. Recent data have shown that low plasma progesterone concentrations during the early luteal phase correlate with poor embryo development (Kerbler et al., 1997; Mann et al., 1999; Mann and Lamming, 2001). For example, embryos recovered at day 16 after insemination from cows with low plasma progesterone concentrations are small and secrete insignificant amounts of tauinterferon. These small embryos also appear to have a limited ability to suppress the luteolytic mechanism in cows (Mann and Lamming, 2001) and, therefore, are unlikely to establish a pregnancy. It is possible that the suppressed plasma progesterone concentrations observed in the BVDVinfected animals compromise fertility by retarding embryo development. Moreover, these data indicate that, in the field, BVDV infection may be one of the factors that reduces progesterone concentrations during the early luteal phase in cows that are inseminated and do not conceive.

The mechanism through which BVDV alters oestradiol and progesterone secretion is unclear but, in the absence of any febrile response, it would appear that the virus exerted a specific effect. Reduced fertility is associated with other viral infections, for example BHV-1 or akabane virus. Infection by these viruses at about the time of insemination is associated with decreased progesterone secretion and necrotic lesions with lymphocytic infiltration in the corpus luteum (Parsonon et al., 1981; Miller and Van Der Maaten, 1986). The origins of luteal dysfunction observed with BHV-1 and akabane virus may differ substantially from the noncytopathogenic BVDV strain used in the present study, although there is evidence that some non-cytopathogenic BVDV strains can cause pathology in vivo. For example, Wilhelmsen et al. (1990) observed petechial lesions in regional lymph nodes and necrosis of mucosal epithelial cells after a non-cytopathogenic BVDV challenge. Grooms et al. (1998b) reported interstitial oophorotis up to day 60 after infection in the absence of replicating virus. Clearly, such lesions could have a significant effect on ovarian function. However, it is unlikely that ovarian pathology was responsible for the endocrine disruption observed in the present study. Histological examination of ovarian tissues collected at post mortem showed no evidence of pathology. Similarly, BVDV antigens were not detected in ovarian tissues by immunofluorescent staining.

Although the possibility of transient ovarian pathology cannot be eliminated in the present study, an alternative explanation can be put forward that centres on the ability of BVDV to induce leucopenia and alter cytokine production. Leucocytes are involved in the angiogenesis and rapid tissue reorganization that take place during luteinization of the ovulatory follicle (Kirsch et al., 1981, 1983; Halme et al., 1985). This is reflected in the massive influx of leucocytes into the thecal layer as ovulation approaches and thereafter as the ovulatory follicle is reorganized into a corpus luteum (Hellberg et al., 1991; Brannstrom and Norman, 1993). Tissue infiltration of leucocytes also accompanies non-cytopathogenic BVDV infection (Wilhelmsen et al., 1990). Therefore, it is conceivable that BVDV infections could alter the number or function of the leucocyte population within the preovulatory follicle and the newly formed corpus luteum. Similarly, the number and function of microglial cells within the central nervous system may also change during the course of infection. This, in turn, may alter hypothalamic-pituitary sensitivity to steroid feedback.

Of particular relevance to the present study is the observation that non-cytopathogenic BVDV can stimulate the secretion of gamma-interferon (IFN- $\gamma$ ) in vivo (B. Charleston, personal communication). IFN- $\gamma$ can reduce $\mathrm{LH}$-induced progesterone secretion in bovine luteal cells after 5 days of culture (Fairchild and Pate, 1991), an observation supported by work on rats (Gosopse et al., 1988). IFN- $\boldsymbol{\gamma}$ also upregulates Fas expression and Fas/Fasligand-mediated killing of thecal and granulosa cells with and without the presence of tumour necrosis factor $\alpha$ (Quirk et al., 1998; Porter et al., 2000). Therefore, the potential also exists for non-cytopathogenic BVDV to disrupt the secretion of ovarian steroids via an interferon- $\boldsymbol{\gamma}$-mediated mechanism.

In conclusion, these data demonstrate that noncytopathogenic BVDV can disrupt spontaneous ovarian steroid secretion to the extent that follicular phase oestradiol secretion is prolonged and the onset of luteal 
progesterone secretion is delayed relative to the time of ovulation. The results of this experiment also demonstrated that non-cytopathogenic BVDV can exert these effects in the presence of a 'normal' follicular phase LH profile. Collectively, these data show that non-cytopathogenic BVDV viraemias during the follicular phase have the potential to reduce cattle fertility by disrupting the capacity of the ovulatory follicle to form a fully competent corpus luteum. The subsequent suppression of progesterone secretion could, in theory, retard early embryo development and compromise maternal recognition of pregnancy.

The authors would like to thank $\mathrm{H}$. Prentice for her technical support. This study was supported jointly by the BBSRC and MAFF.

\section{Reference}

Anderson CA, Higgins RJ, Smith ME and Osburn BI (1987) Virus-induced decrease in thyroid hormone levels with associated hypomyelination Laboratory Investigation 57 168-175

Beard AJ, Castillo RJ, McLeod BJ, Glencross RG and Knight PG (1990) Comparison of the effects of crude and highly purified bovine inhibin $\left(M_{\mathrm{r}} 32000\right)$ on plasma concentrations of $\mathrm{FSH}$ and $\mathrm{LH}$ in chronically ovariectomized prepubertal heifers Journal of Endocrinology 125 21-30

Booth PJ, Stevens DA, Collins ME and Brownlie J (1995) Detection of bovine viral diarrhoea virus antigen and RNA in oviduct and granulosa cells of persistently infected cattle Journal of Reproduction and Fertility 105 17-24

Brannstrom M and Norman RJ (1993) Involvement of leukocytes and cytokines in the ovulatory process and corpus luteum function Human Reproduction 8 1762-1775

Brownlie J, Clarke MC and Howard CJ (1989) Experimental infection of cattle in early pregnancy with a cytopathic strain of bovine virus diarrhoea virus Research in Veterinary Science 46 307-311

Fairchild DL and Pate JL (1991) Modulation of bovine luteal cell synthetic capacity by interferon-gamma Biology of Reproduction 44 357-363

Fray MD, Prentice H, Clarke MC and Charleston B (1998) Immunohistochemical evidence for the localization of bovine viral diarrhea virus, a single stranded RNA virus, in ovarian oocytes in the cow Veterinary Pathology 253-259

Fray MD, Mann GE, Clarke MC and Charleston B (1999) Bovine viral diarrhea virus: its effects on estradiol, progesterone and prostaglandin secretion in the cow Theriogenology 51 1533-1546

Frey H-R and Liess B (1971) Vermehrungskinetik und Verwendbarkiet eines stark zytopathogenen VD-MD-Virusstammes für diagnostische Untersuchungen mit der Mikrotiter-Methode Zentralblatt fur Veterinarmedizin Reihe 18B 61-71

Gosopse WC, Tuchel T and Kasson BG (1988) g-interferon inhibits rat granulosa cell differentiation in culture Biochemical and Biophysical Research Communications 157 891-897

Grooms DL, Ward LA and Brook KV (1996) Morphologic changes and immunohistochemical detection of viral antigen in ovaries from cattle persistently infected with bovine viral diarrhea virus American Journal of Veterinary Research $\mathbf{5 7}$ 830-833

Grooms DL, Brock KV, Pate JL and Day ML (1998a) Changes in ovarian follicles following acute infection with bovine viral diarrhea virus Theriogenology 49 595-605

Grooms DL, Brock KV and Ward LA (1998b) Detection of bovine viral diarrhea virus in the ovaries of cattle acutely infected with bovine viral diarrhea virus Journal of Veterinary Diagnostics and Investigation 10 125-129

Guerin B, Chaffaux S, Marquant Le Guienne B, Allietta M and Thibier M (1992) IVF and IV culture of bovine embryos using semen from a bull persistently infected with BVDV Theriogenology 37217 (Abstract)

Haines DM, Clarke EG and Dubovi EJ (1992) Monoclonal antibody-based immunohistochemical detection of bovine viral diarrhea virus in formalin-fixed, paraffin-embedded tissues Veterinary Pathology 29 $27-32$

Halme J, Hammond MG, Syrop CH and Talbert LM (1985) Peritoneal macrophages modulate human granulosa-luteal cell progesterone production Journal of Clinical Endocrinology and Metabolism 61 912-916

Haresign W, Foster JP, Hance NB, Crighton DB and Lamming GE (1975) Progesterone levels following treatment of seasonally anestrous ewes with synthetic LH-releasing hormone Journal of Reproduction and Fertility 43 269-279

Hellberg DM, Thomsen P, Janson PO and Brannstrom M (1991) Leukocyte supplementation increases the luteinizing-hormone induced ovulation rate in the in-vitro perfused rat ovary Biology of Reproduction $\mathbf{4 4}$ 791-797

Hewicker-Trautwein M, Liess B and Trautwein G (1995) Brain lesions in calves following transplacental infection with bovine-virus diarrhoea virus Journal of Veterinary Medicine 42 65-77

Kafi M, McGowan MR, Kirkland PD and Jillella D (1997) The effect of bovine pestivirus infection on the superovulatory response of Friesian heifers Theriogenology 48 985-996

Kerbler TL, Buhr MM, Jordan LT, Leslie KE and Walton JS (1997) Relationship between maternal plasma progesterone concentration and interferon-tau synthesis by the conceptus in cattle Theriogenology $\mathbf{4 7}$ 703-714

Kirsch TM, Friedman AC, Vogel RL and Flickinger GL (1981) Macrophages in corpora lutea of mice: characterisation and effects on steroid secretion Biology of Reproduction 25 629-638

Kirsch TM, Vogel L and Flickinger GL (1983) Macrophages: a source of luteotropic cybernins Endocrinology 113 1910-1912

Larsson B, Niskanen R and Alenius S (1994) Natural infection with bovine virus diarrhea virus in a dairy herd: a spectrum of symptoms including early reproductive failure and retained placenta Animal Reproduction Science 36 37-48

Leoder JD, Van de Wiel DFM and Gaines Das RE (1987) An international collaborative study on the first international standard of bovine luteinizing hormone for immunoassay Journal of Reproduction and Fertility 79 145-152

McGowan MR, Kirkland PD, Richards SG and Littlejohns IR (1993) Increased reproductive losses in cattle infected with bovine pestivirus around the time of insemination Veterinary Record 133 39-43

Mann GE and Lamming GE (2001) Relationship between maternal endocrine environment, early embryo development and inhibition of the luteolytic mechanism in cows Reproduction 121 175-180

Mann GE, Lamming GE and Fray MD (1995) Plasma estradiol and progesterone during early pregnancy in the cow and the effects of treatment with buserelin Animal Reproduction Science 37 121-131

Mann GE, Lamming GE, Robinson RS and Wathes DC (1999) The regulation of interferon-t production and uterine hormone receptors during early pregnancy Journal of Reproduction and Fertility Supplement 54 317-328

Miller JM and Van Der Maaten MJ (1986) Experimentally induced infectious bovine rhinotracheitis virus infection during early pregnancy: effect on the bovine corpus luteum and conceptus American Journal of Veterinary Research 47 223-228

Nettleton PF and Entrican G (1995) Ruminant pestiviruses British Veterinary Journal 151 615-642

Parsonon IM, Della-Porta AJ, Snowdon WA and O'Halloran ML (1981) The consequences of infection of cattle with Akabane virus at the time of insemination Journal of Comparative Pathology 91 611-619

Pierson RA and Ginther OJ (1987) Ultrasonographic appearance of the bovine uterus during the estrous cycle Journal of the American Veterinary Medicine Association 190 995-1001

Porter DA, Vickers LS, Cowan RG, Huber SC and Quirk SM (2000) Expression and function of Fas antigen vary in bovine granulosa and theca cells during ovarian follicular development and atresia Biology of Reproduction 62 62-66

Quirk SM, Porter DA, Huber SC and Cowan RG (1998) Potentiation of Fasmediated apoptosis of murine granulosa cells by interferon-gamma, tumor necrosis factor-alpha, and cycloheximide Endocrinology 139 4860-4869 
Roeder PL and Drew TW (1984) Mucosal disease of cattle: a late sequel to foetal infection Veterinary Record 114 309-313

Stringfellow DA, Riddell KP, Brock KV, Riddell MG, Galik KP, Wright JC and Hasler JF (1997) In vitro fertilization and in vitro culture of bovine embryos in the presence of non-cytopathic bovine viral diarrhoea virus Theriogenology 48 171-183

Stringfellow DA, Riddell KP, Galik PK, Damiani P, Bishop MD and Wright JC (2000) Quality controls for bovine viral diarrhea virus-free IVF embryos Theriogenology 53 827-839

Van der Maaten MJ and Miller JM (1985) Ovarian lesions in heifers exposed to infectious bovine rhinotracheitis virus by non-genital routes on the day after breeding Veterinary Microbiology 10 155-163

Vanroose G, Nauwynck H, Van Soom A, Vanopdenbosch E and de Kruif A (1998) Replication of cytopathic and non-cytopathic bovine viral diarrhoea virus in zona-pellucida free and zona-intact in vitro-produced bovine embryos and the effects on embryo quality Biology of Reproduction 58 857-866
Virakul P, Fahning ML, Joo HS and Zemjanis R (1998) Fertility of cows challenged with a cytopathic bovine viral diarrhea virus during an outbreak of spontaneous infection with a non-cytopathic strain Theriogenology 29 441-449

Wilhelmsen CL, Bolin SR, Ridpath JF, Cheville NF and Kluge JP (1990) Experimental primary postnatal bovine viral diarrhoea viral infections in six-month-old calves Veterinary Pathology 27 243-253

Zurovac OV, Stringfellow DA, Brock KV, Riddell MG and Wright JC (1994) Noncytopathic bovine viral diarrhea virus in a system for in vitro production of bovine embryos Theriogenology 41 841-853

Received 11 June 2001

First decision 26 July 2001.

Revised manuscript received 18 October 2001.

Accepted 25 October 2001. 